University of Nebraska - Lincoln

DigitalCommons@University of Nebraska - Lincoln

Faculty Papers and Publications in Animal

Science

Animal Science Department

January 1970

\title{
EFFECT OF FEEDING-FASTING INTERVAL ON FINISHING PIGS: BLOOD UREA AND SERUM LIPID, CHOLESTEROL AND PROTEIN CONCENTRATIONS
}

T. L. Veum

Cornell University

W. G. Pond

Cornell University

E. F. Walker Jr.

Cornell University

L. Dale Van Vleck

University of Nebraska-Lincoln, dvan-vleck1@unl.edu

Follow this and additional works at: https://digitalcommons.unl.edu/animalscifacpub

Part of the Animal Sciences Commons

Veum, T. L.; Pond, W. G.; Walker, E. F. Jr.; and Van Vleck, L. Dale, "EFFECT OF FEEDING-FASTING INTERVAL ON FINISHING PIGS: BLOOD UREA AND SERUM LIPID, CHOLESTEROL AND PROTEIN CONCENTRATIONS" (1970). Faculty Papers and Publications in Animal Science. 327.

https://digitalcommons.unl.edu/animalscifacpub/327

This Article is brought to you for free and open access by the Animal Science Department at DigitalCommons@University of Nebraska - Lincoln. It has been accepted for inclusion in Faculty Papers and Publications in Animal Science by an authorized administrator of DigitalCommons@University of Nebraska - Lincoln. 
Veum, T. L., W. G. Pond, E. F. Walker, Jr., and L. D. Van Vleck. 1970. Effect of feeding-fasting interval on finishing pigs: blood urea and serum lipid, cholesterol, and protein concentrations. Journal of Animal Science 30:388-393.

Abstract: A system of restricted feeding in which feed is entirely withheld for intervals of 24, 48 or $72 \mathrm{hr}$. following a 24-hr. period of ad libitum feeding in continuous sequence throughout the finishing period depresses weight gain and efficiency of feed utilization in direct relation to duration of the fasting period and has marked associated effects on carcass measurements, gland and organ weights and a small effect on fatty acid composition of the back fat (Veum et al., 1970). Cohn (1963) and Leveille and Hanson $(1965,1966)$ have shown marked changes in metabolism of nutrients and in body composition associated with frequency of meal intake in laboratory animals. The work reported herein was included as a part of the experiment of Veum et al. (1970). The purpose was to determine the effects of feeding-fasting interval of finishing pigs on several blood parameters in terms of postprandial and long-term changes in concentrations associated with feeding sequence.

Copyright $\odot 1970$ American Society of Animal Science. Used by permission. 


\title{
EFFECT OF FEEDING-FASTING INTERVAL ON FINISHING PIGS: BLOOD UREA AND SERUM LIPID, CHOLESTEROL AND PROTEIN CONCENTRATIONS
}

\author{
T. L. Veum, ${ }^{1}$ W. G. Pond, E. F. Walker, Jr. and L. D. Van Vleck \\ Cornell University, Ithaca, New York ${ }^{2,3}$
}

\begin{abstract}
A SYSTEM of restricted feeding in which A feed is entirely withheld for intervals of 24,48 or $72 \mathrm{hr}$. following a 24-hr. period of ad libitum feeding in continuous sequence throughout the finishing period depresses weight gain and efficiency of feed utilization in direct relation to duration of the fasting period and has marked associated effects on carcass measurements, gland and organ weights and a small effect on fatty acid composition of the back fat (Veum et al., 1970). Cohn (1963) and Leveille and Hanson (1965, 1966) have shown marked changes in metabolism of nutrients and in body composition associated with frequency of meal intake in laboratory animals.

The work reported herein was included as a part of the experiment of Veum et al. (1970). The purpose was to determine the effects of feeding-fasting interval of finishing pigs on several blood parameters in terms of postprandial and long-term changes in concentrations associated with feeding sequence.
\end{abstract}

\section{Experimental Procedure}

Blood samples were obtained at 3-week intervals from 32 Yorkshire finishing pigs from $49 \mathrm{~kg}$ body weight to slaughter at approximately 90 kilograms. Four feeding sequences were involved, each involving eight individually penned pigs. The feeding sequences were: (1) continuously ad libitum-fed from a selffeeder (control); (2) ad libitum-fed $24 \mathrm{hr}$., fasted $24 \mathrm{hr}$.; (3) ad libitum-fed $24 \mathrm{hr}$., fasted $48 \mathrm{hr}$.; (4) ad libitum-fed $24 \mathrm{hr}$., fasted 72 hours. At each 3 -week bleeding interval a blood sample (20 to $25 \mathrm{ml}$ ) was obtained from the anterior vena cava on 4 consecutive days to represent periods of fasting of $10,34,58$ and $82 \mathrm{hr}$., since feed was withheld from pigs approximately $10 \mathrm{hr}$. prior to bleeding in treat-

\footnotetext{
1 Present address: Department of Animal Science, University of Missouri, Columbia 65201

2 Department of Animal Science.

3 The assistance of Ruth Whetzel, J. A. Dunn, R. Carpenter, H. Perrine, R. Banis, J. O'Connor and J. Logomarsino is gratefully acknowledged.
}

ment groups that had had access to feed on that particular day. Blood urea was determined on heparinized samples (Coulombe and Favreau, 1963) and lipid (Folch, Lees and Sloane-Stanley, 1957) cholesterol (Mann, 1961) and protein (Gornall, Bardawill and David, 1949) in the serum were determined from centrifuged non-heparinized blood tubes. The difference in rate of weight gain among pigs in the four treatment groups resulted in only two 3-week bleeding intervals for the control pigs (treatment 1 ) and three for pigs on treatment 2. Blood samples were obtained during five 3-week intervals from pigs on treatment 3 and during eight 3 -week intervals from those on treatment 4 .

The data were analyzed by unweighted squares of means in a 2-way classification (treatment and replicate) for each period separately with appropriate orthogonal comparisons and by one-way (hour of fasting) analysis of variance within each treatment to test the effect of fasting on each blood component. Correlation coefficients (Steel and Torrie, 1960) were obtained between blood parameters and several performance and carcass criteria from the data of Veum et al. (1970).

\section{Results and Discussion}

The concentrations of serum lipid, cholesterol and protein and blood urea were strikingly unresponsive to dietary treatment (feeding-fasting interval) as judged by the comparison of mean values at 3 -week intervals (tables 1 to 4 ). This lack of response indicates a high degree of homeostatic control of these parameters in growing swine in a good state of protein nutrition and severely restricted in energy intake. There were scattered linear, cubic, quadratic, quartic and quintic time effects across 3-week bleeding intervals within treatments for all of the blood components. Blood sampling for 4 consecutive days at each 3 -week interval did not have any significant $(\mathrm{P}<.05)$ effect on the concentrations of the blood and serum components.

The results for serum lipids (table 1 ) con- 
TABLE 1. EFFECT OF FEEDING-FASTING INTERVAL AND TIME TREND (3-WEEK INTERVALS) ON SERUM LIPID CONCENTRATION IN FINISHING PIGS ${ }^{\mathrm{a}}$

\begin{tabular}{|c|c|c|c|c|}
\hline \multirow[b]{2}{*}{ Period $^{b}$} & \multicolumn{4}{|c|}{ Treatment } \\
\hline & $\begin{array}{c}\text { (con- } \\
\text { trol) }\end{array}$ & $\begin{array}{c}2 \\
\text { (adlib. } \\
1 \text { day, } \\
\text { fasted } \\
1 \text { day) }\end{array}$ & $\begin{array}{c}3 \\
\text { (ad lib. } \\
1 \text { day, } \\
\text { fasted } \\
2 \text { days) }\end{array}$ & $\begin{array}{c}4 \\
\text { (ad lib. } \\
1 \text { day, } \\
\text { fasted } \\
3 \text { days) }\end{array}$ \\
\hline & \multicolumn{4}{|c|}{$\mathrm{Mg} / 100 \mathrm{ml}$} \\
\hline$O$ (initial) & 342 & 340 & 342 & 334 \\
\hline 1 & 345 & 353 & 347 & 346 \\
\hline 2 & 344 & 351 & 339 & 357 \\
\hline 3 & $\ldots$ & 351 & 339 & 342 \\
\hline 4 & $\ldots$ & $\ldots$ & 334 & 343 \\
\hline 5 & $\ldots$ & $\ldots$ & 345 & 349 \\
\hline $6-10^{\circ}$ & & & & 318 \\
\hline Overall mean ${ }^{c}$ & 344 & 351 & 341 & 334 \\
\hline \multicolumn{5}{|c|}{$\begin{array}{l}\text { a Four pigs in each of two replicates in each treatment } \\
\text { group. Each mean consists of } 32 \text { values (eight pigs } 4 \text { days), } \\
\text { except mean for period } 6 \text { to } 10 \text { which contains more. One pig } \\
\text { in each replicate of treatment } 4 \text { died near the end of the } \\
\text { experiment, one during surgery for a prolapsed rectum and } \\
\text { one with advanced visceral lymphosarcoma. } \\
\text { b Each period is } 3 \text { weeks, except last period in each treat- } \\
\text { ment which is less. } \\
\text { 'Not statistically analyzed. }\end{array}$} \\
\hline
\end{tabular}

cur with those of Morrow et al. (1963) who found no significant differences in plasma lipid levels between fasted pigs and fed controls. Serum lipid values obtained in this experiment are similar to those reported by Babatunde et al. (1967) but are higher than those reported by other workers (Perry, Beeson and Vosteen, 1953; Bowland and Hironaka, 1957; Self, 1959; Morrow et al., 1963; Tremere, Owen and Bell, 1966). These differences may be due in part to the methods used.

TABLE 2. EFFECT OF FEEDING-FASTING INTERVAL AND TIME TREND (3-WEEK INTERVALS) ON SERUM CHOLESTEROL CONCENTRATON IN FINISHING PIGS ${ }^{a}$

\begin{tabular}{|c|c|c|c|c|}
\hline \multirow[b]{2}{*}{ Period $^{b}$} & \multicolumn{4}{|c|}{ Treatment } \\
\hline & $\begin{array}{c}1 \\
\text { (con- } \\
\text { trol) }\end{array}$ & $\begin{array}{c}2 \\
\text { (ad lib. } \\
1 \text { day, } \\
\text { fasted } \\
1 \text { day) }\end{array}$ & $\begin{array}{c}3 \\
\text { (ad lib. } \\
1 \text { day, } \\
\text { fasted } \\
2 \text { days) }\end{array}$ & $\begin{array}{c}4 \\
\text { (ad lib. } \\
1 \text { day, } \\
\text { fasted } \\
3 \text { days) }\end{array}$ \\
\hline & \multicolumn{4}{|c|}{$\mathrm{Mg} / 100 \mathrm{ml}$} \\
\hline 0 (initial) & 138 & 142 & 139 & 144 \\
\hline 1 & 126 & 127 & 133 & 126 \\
\hline 2 & 142 & 142 & 141 & 145 \\
\hline 3 & $\ldots$ & 138 & 134 & 143 \\
\hline 4 & $\ldots$ & $\ldots$ & 134 & 143 \\
\hline 5 & $\ldots$ & $\ldots$ & 135 & 141 \\
\hline $6-10^{c}$ & $\ldots$ & & & 136 \\
\hline Overall mean ${ }^{c}$ & 134 & 136 & 135 & 138 \\
\hline
\end{tabular}

TABLE 3. EFFECT OF FEEDING-FASTING INTERVAL AND TIME TREND (3-WEEK INTERVALS) ON BLOOD UREA CONCENTRATION IN FINISHING PIGS ${ }^{\text {a }}$

\begin{tabular}{|c|c|c|c|c|}
\hline \multirow[b]{2}{*}{ Period $^{\mathrm{b}}$} & \multicolumn{4}{|c|}{ Treatment } \\
\hline & $\begin{array}{c}\text { (con- } \\
\text { trol) }\end{array}$ & $\begin{array}{c}2 \\
\text { (adlib. } \\
1 \text { day, } \\
\text { fasted } \\
1 \text { day) }\end{array}$ & $\begin{array}{c}3 \\
\text { (ad lib. } \\
1 \text { day, } \\
\text { fasted } \\
2 \text { days) }\end{array}$ & $\begin{array}{c}4 \\
\text { (adlib. } \\
1 \text { day, } \\
\text { fasted } \\
3 \text { days) }\end{array}$ \\
\hline & \multicolumn{4}{|c|}{$\mathrm{Mg} / 100 \mathrm{ml}$} \\
\hline$O$ (initial) & 38 & 38 & 40 & 39 \\
\hline 1 & 43 & 44 & 44 & 41 \\
\hline 2 & 40 & 45 & 40 & 43 \\
\hline 3 & 43 & 42 & 40 & 42 \\
\hline 4 & .. & . & 38 & 40 \\
\hline 5 & .. & . & 39 & 32 \\
\hline $6-10^{c}$ & & & & 37 \\
\hline Overall mean ${ }^{c}$ & 42 & 43 & 40 & 39 \\
\hline
\end{tabular}

a Each mean consists of 32 values (see footnote a, table 1). b Each period is 3 weeks, except last period in each treatment which is less.

Not statistically analyzed.

There were significant $(\mathrm{P}<.05)$ differences associated with the length of fast within treatments for all of the blood and serum components measured (table 5). The serum lipid levels of the pigs were significantly increased after $34 \mathrm{hr}$. of fasting in treatments 2,3 and 4 as well as after $58 \mathrm{hr}$. of fasting in treatment 3 when compared to the 10-hr. fast. The increase in serum lipid level is probably related to mobilization of tissue lipids to meet energy needs during fasting. The concentrations of serum cholesterol increased significantly with each progressive increase in length of fast

TABLE 4. EFFECT OF FEEDING-FASTING INTERVAL AND TIME TREND (3-WEEK INTERVALS) ON SERUM PROTEIN CONCENTRATION IN FINISHING PIGS ${ }^{\text {a }}$

\begin{tabular}{|c|c|c|c|c|}
\hline \multirow[b]{2}{*}{ Period $^{b}$} & \multicolumn{4}{|c|}{ Treatment } \\
\hline & $\begin{array}{c}\text { (con- } \\
\text { trol) }\end{array}$ & $\begin{array}{c}2 \\
\text { (ad lib. } \\
1 \text { day, } \\
\text { fasted } \\
1 \text { day) }\end{array}$ & $\begin{array}{c}3 \\
\text { (ad lib. } \\
1 \text { day, } \\
\text { fasted } \\
2 \text { days) }\end{array}$ & $\begin{array}{c}4 \\
\text { (ad lib. } \\
1 \text { day, } \\
\text { fasted } \\
3 \text { days) }\end{array}$ \\
\hline & \multicolumn{4}{|c|}{$\mathrm{g} / 100 \mathrm{ml}$} \\
\hline 0 (initial) & 7.1 & 7.0 & 7.3 & 7.0 \\
\hline 1 & 7.2 & 7.4 & 7.5 & 7.2 \\
\hline 2 & 7.4 & 7.5 & 7.5 & 7.5 \\
\hline 3 & $\ldots$ & 7.5 & 7.5 & 7.8 \\
\hline 4 & $\ldots$ & $\ldots$ & 7.9 & 8.0 \\
\hline 5 & $\ldots$ & $\ldots$ & 7.4 & 7.1 \\
\hline $6-10^{c}$ & & & & 7.3 \\
\hline Overall mean ${ }^{c}$ & 7.3 & 7.4 & 7.5 & 7.4 \\
\hline
\end{tabular}

a Each mean consists of 16 values (four pigs in each treatment group $x 4$ days).

b Each period is 3 weeks, except last period in each treatment which is less.

c Not statistically analyzed. 
TABLE 5. EFFECT OF LENGTH OF FAST ON CHANGES IN BLOOD COMPONENT LEVELS WITHIN TREATMENTS ${ }^{a}$

\begin{tabular}{|c|c|c|c|c|}
\hline \multirow[b]{2}{*}{ Hours of fasting } & \multicolumn{4}{|c|}{ Treatment no. } \\
\hline & $\begin{array}{c}1 \\
\text { (control) }\end{array}$ & $\begin{array}{l}{ }^{2} \\
\text { (ad lib. } 1 \text { day, } \\
\text { fasted } 1 \text { day) }\end{array}$ & $\begin{array}{c}3 \\
(a d l i b .1 \text { day } \\
\text { fasted } 2 \text { days) }\end{array}$ & $\begin{array}{c}4^{4} \\
\text { (ad lib. } 1 \text { day } \\
\text { fasted } 3 \text { days) }\end{array}$ \\
\hline & \multicolumn{4}{|c|}{ Serum liquids, $\mathrm{mg} / 100 \mathrm{ml}$} \\
\hline 10 & $344 \pm 35^{\mathrm{c}}$ & $344 \pm 34^{\circ}$ & $321 \pm 39^{\circ}$ & $297 \pm 41^{\mathrm{c}}$ \\
\hline 34 & $\ldots \ldots$ & $358 \pm 33^{c}$ & $346 \pm 37^{\circ}$ & $324 \pm 33^{\mathrm{c}}$ \\
\hline 58 & $\ldots \ldots$ & $\ldots \ldots$ & $362 \pm 35^{\mathrm{e}}$ & $357 \pm 42$ \\
\hline \multirow[t]{2}{*}{82} & $\ldots \ldots$ & $\ldots \ldots$ & $\ldots \ldots$ & $364 \pm 46$ \\
\hline & \multicolumn{4}{|c|}{ Serum cholesterol, $\mathrm{mg} / 100 \mathrm{ml}$} \\
\hline 10 & $134 \pm 10$ & $133 \pm 13^{c}$ & $124 \pm 16^{\mathrm{c}}$ & $124 \pm 15^{c}$ \\
\hline 34 & $\ldots \ldots$ & $140 \pm 14^{c}$ & $135 \pm 16^{c}$ & $132 \pm 15^{\mathrm{e}}$ \\
\hline 58 & $\ldots \ldots$ & $\ldots \ldots$ & $152 \pm 19^{\mathrm{c}}$ & $146 \pm 16^{\circ}$ \\
\hline \multirow[t]{2}{*}{82} & $\ldots \ldots$ & $\ldots \ldots$ & $\ldots \ldots$ & $153 \pm 16^{c}$ \\
\hline & \multicolumn{4}{|c|}{ Blood urea, $\mathrm{mg} / 100 \mathrm{ml}$} \\
\hline 10 & $42 \pm 6$ & $51 \pm 10^{\mathrm{c}}$ & $48 \pm 9^{\circ}$ & $50 \pm 10^{c}$ \\
\hline 34 & $\ldots \ldots$ & $34 \pm 7^{\circ}$ & $35 \pm 11$ & $35 \pm 8$ \\
\hline \multirow{3}{*}{$\begin{array}{l}58 \\
82\end{array}$} & $\ldots \ldots$ & $\ldots$ & $36 \pm 7$ & $34 \pm 6$ \\
\hline & $\ldots \ldots$ & $\ldots$ & $\ldots$ & $37 \pm 8$ \\
\hline & \multicolumn{4}{|c|}{ Serum protein, $g / 100 \mathrm{ml}$} \\
\hline 10 & $7.1 \pm 0.4$ & $7.1 \pm 0.5^{c}$ & $7.4 \pm 0.4^{\circ}$ & $7.0 \pm 0.5^{\mathrm{c}}$ \\
\hline 34 & $\ldots \ldots$ & $7.8 \pm 0.6^{\circ}$ & $7.7 \pm 0.4$ & $7.4 \pm 0.5$ \\
\hline 58 & $\ldots \ldots$ & $\ldots \ldots \ldots$ & $7.7 \pm 0.6$ & $7.5 \pm 0.6$ \\
\hline 82 & $\ldots \ldots$ & $\ldots \ldots \ldots$ & $\ldots \ldots \ldots$ & $7.7 \pm 0.5$ \\
\hline
\end{tabular}

a Sample sizes ranged from 44 to $69(\overline{\mathrm{X}}=59)$ for all means except serum protein which ranged from 24 to $40 \quad(\overline{\mathrm{X}}=29)$.

Mean with standard deviation.

e Differs significantly ( $\mathrm{P}<.05)$ from all other means within treatments.

within treatments 2, 3 and 4 (table 5). Fasting (Kornegay et al., 1964; Fausch, Richmond and Anderson, 1968) and restricted feeding (Calloway, Hilf and Munson, 1962) have both been reported to elevate serum cholesterol levels in swine. Mean values for serum cholesterol in this experiment are similar to those reported by Heidenreich, Garwood and Harrington (1964). Level of protein and source of fat in swine diets affect both serum lipids (Self, 1959) and serum cholesterol (Bragdon, Zeller and Stevenson, 1957; Barnes et al., 1959; Rowsell, Mustard and Downie, 1965; Greer et al., 1966). Rowsell, Downie and Mustard (1958) reported that serum cholesterol concentration was not affected by butter or margarine supplementation of isocaloric diets.

Blood urea levels were significantly reduced and serum protein concentrations significantly increased after $34 \mathrm{hr}$. of fasting compared to the $10 \mathrm{hr}$. fast in treatments 2,3 and 4 (table 5 ). These increased levels were maintained for the duration of the 58-hr. fast in treatment 3 and the 82 -hr. fast in treatment 4 . The mean values for blood urea are in agreement with those reported by McCance (1960). Kornegay et al. (1964) observed a significant reduction in serum urea nitrogen associated with pro- longed fasting which agrees with the data reported here. Serum protein values obtained in the present experiment were similar to those reported by other workers for growing-finishing swine (Knill, Podleski and Childs, 1958; Barnes et al., 1959; Miller et al., 1961; Babatunde et al., 1967). Kornegay et al. (1964) observed a reduced serum protein in fasted pigs, but Calloway et al. (1962) found no effect of chronic feed restriction on total serum protein or electrophoretic pattern of serum protein in miniature swine.

Total correlation coefficients were obtained among variables (table 6). The correlations between the middle and outer layers of back fat for each fatty acid were significant $(\mathrm{P}<$ $.01)$ for myristic $(0.69)$, palmitic (0.53), stearic $(0.85)$, oleic $(0.68)$ and linoleic $(0.70)$ acids. The correlations between the overall mean and the mean of the final bleeding period were significant $(\mathrm{P}<.01)$ for the serum levels of lipid (0.66), cholesterol (0.84), protein $(0.76)$ and urea (0.77).

The significant negative correlation $(-.39)$ between age at slaughter and serum lipid level obtained in this experiment is contrary to the significant positive within pig correlation (0.40) obtained when all groups were fed $a d$ 


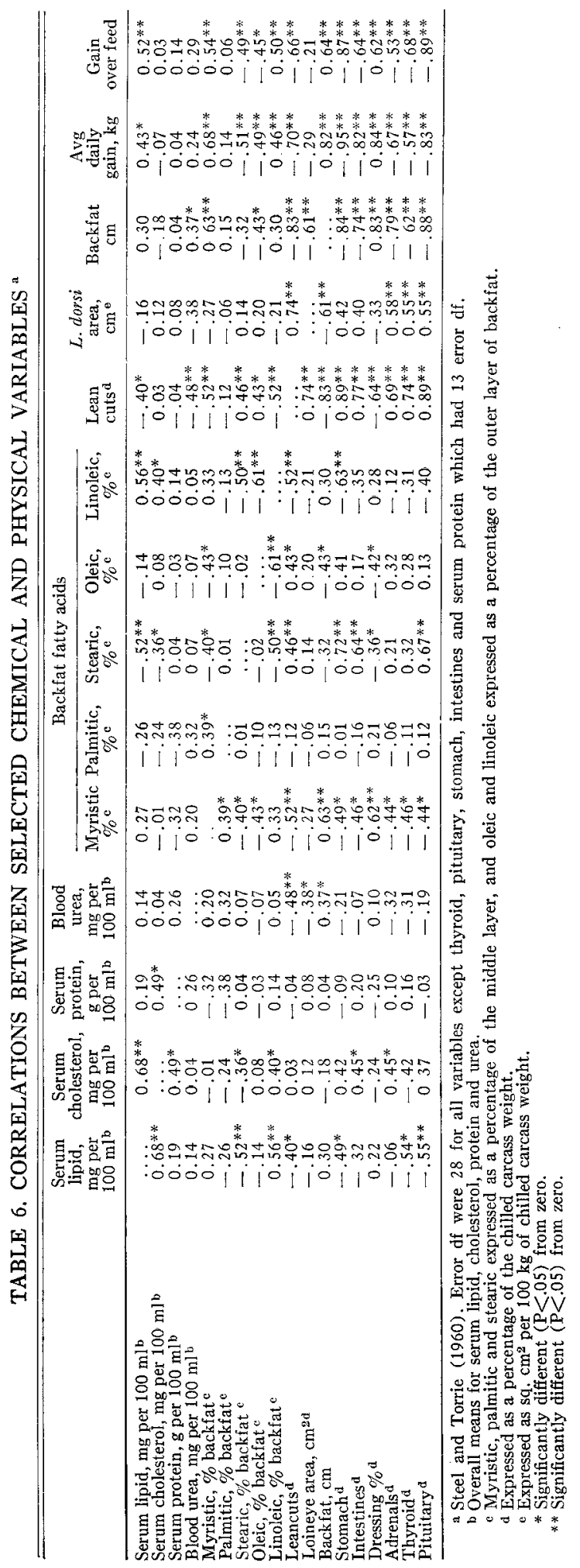


libitum (Self, 1959). The standard partial regression coefficients reported by Self (1959) indicated that weight was more important than age in the prediction of plasma lipid levels. The significant relationship between serum lipid level and average daily gain is essentially in agreement with the significant within treatment correlation reported by Self (1959). Significant correlations were obtained between the serum levels of lipid and cholesterol, and cholesterol and protein, although no significant associations were found between the other blood components (table 6). Serum lipid level was not significantly associated with either backfat thickness or $l$. dorsi area which supports the work by Tremere et al. (1966) but disagrees with Morrow et al. (1956) and Bowland and Hironaka (1957). The low correlation between serum cholesterol and average daily gain contradicts the highly significant correlation reported by Heidenreich $e t$ al. (1964). However, serum cholesterol level was not significantly associated with backfat thickness, $l$. dorsi area or length which is in good agreement with the results of Heidenreich $e t$ al. (1964) and Tremere et al. (1966). The magnitude of the correlations between the blood components and the carcass measurements in this experiment confirms the statement by Tremere et al. (1966) that they would have little value in predicting carcass merit.

Serum lipid and serum cholesterol were associated negatively with the percentage of stearic acid and associated positively with the percentage of linoleic acid in the back fat. Stearic and oleic acids had significant negative correlations with myristic acid, linoleic acid, average daily gain and gain:feed ratio; and significant positive associations with the percentage of lean cuts. The weights of stomach, intestines, adrenals, thyroid and pituitary glands, as a percentage of the chilled carcass weight, had negative relationships with average daily gain and gain per unit feed consumed. Carcass length was not significantly associated with any of the pooled variables. The results of this experiment indicate that the length of fast ( 10 to $82 \mathrm{hr}$.) had a significant $(\mathrm{P}<.05)$ effect on the concentrations of the blood and serum components measured even though the dietary treatments did not significantly affect the 3-week interval means. This demonstrates the remarkable capacity of the pig to maintain blood homeostasis despite severe restriction in feed consumption and prolonged periods of intermittent fasting.

\section{Summary}

Blood samples were obtained for 4 consecutive days at 3 -week intervals from 32 individually-fed Yorkshire finishing pigs for blood urea and serum cholesterol, lipid and protein determinations. Four feeding sequences were involved: (1) continuously ad libitum; (2) ad libitum $24 \mathrm{hr}$., fasted $24 \mathrm{hr}$.; (3) ad libitum $24 \mathrm{hr}$., fasted $48 \mathrm{hr}$.; (4) ad libitum 24 hr., fasted $72 \mathrm{hr}$. Feed was withheld from pigs approximately $10 \mathrm{hr}$. prior to bleeding in treatment groups that had access to feed on that particular day. Thus periods of fasting were $10,34,58$ and 82 hours.

The concentrations of all four blood and serum components were strikingly unresponsive to dietary treatment as determined by the comparison of mean values at 3-week intervals. There were scattered linear, cubic, quadratic, quartic and quintic time effects across 3-week bleeding intervals within treatments for all four blood and serum components. Blood sampling for 4 consecutive days at each 3-week interval did not significantly $(\mathrm{P}<.05)$ affect concentrations of the blood and serum components.

Significant $(\mathrm{P}<.05)$ differences were associated with the length of fast within treatments for all four blood and serum components. Serum lipid levels were significantly increased after $34 \mathrm{hr}$. of fasting when compared to the $10-\mathrm{hr}$. fast, probably as a result of mobilization of tissue lipids to meet energy needs during fasting. Serum cholesterol concentrations increased significantly with each progressive increase in length of fast (within treatments) when compared to the 10-hr. fast. Blood urea levels were significantly reduced and serum protein concentrations significantly increased after $34 \mathrm{hr}$. of fasting as compared to the 10-hr. fast. These increased levels were maintained for the duration of the fast.

-Serum lipid level was significantly correlated with average daily gain and feed:gain ratio, but not backfat thickness or $l$. dorsi area. Serum levels of lipid and cholesterol were negatively correlated with stearic acid in the backfat and positively correlated with linoleic acid in the backfat.

It is concluded that blood urea and serum lipid, cholesterol and protein are influenced by long periods of fasting in finishing swine but that these effects are transient and not apparent when observing mean values at 3 week intervals in animals in various feedingfasting sequences. 


\section{FASTING INTERVAL AND BLOOD COMPOSITION OF PIGS}

\section{Literature Cited}

Babatunde, G. M., W. G. Pond, L. Krook, L. D. Van Vleck, E. F. Walker, Jr. and P. Chapman. 1967. Effect of dietary safflower oil or hydrogenated coconut oil on growth rate and on some blood and tissue components of pigs fed a fat-free diet. J. Nutr. $92: 293$

Barnes, R. H., E. Kwong, W. Pond, R. Lowrey and J. K. Loosli. 1959. Dietary fat and protein and serum cholesterol. II. Young swine. J. Nutr. $69: 269$.

Bowland, J. P. and Hironaka. 1957. Relationship of plasma lipid levels to carcass quality and rate of gain in swine. J. Anim. Sci. 16:62.

Bragdon, J. H., J. H. Zeller and J. W. Stevenson. 1957. Swine and experimental atherosclerosis. Proc. Soc. Exp. Biol. Med, 95:282.

Calloway, D. H., R. Hilf and A. H. Munson. 1962. Effects of chronic food restriction in swine. J. Nutr. 76:365.

Cohn, C. 1963. Feeding frequency and body composition. Annals. N. Y. Acad. Sci. 110:395.

Coulombe, J. J. and L. Favreau. 1963. A new simple semimicio method for colorimetric determination of urea. Clin. Chem. 9:102.

Fausch, H. D., R. Richmond and T. A. Anderson. 1968. Influence of fasting on body composition and tissue cholesterol levels in swine. J. Anim. Sci $27: 1273$.

Folch, J., M. Lees and G. H. Sloane-Stanley. 1957. A simple method for the isolation and purification of total lipids from animal tissue. J. Biol. Chem. 226:497.

Gornall, A. G., C. J. Bardawill and M. M. David. 1949. Determination of serum proteins by means of the biuret reaction. J. Biol. Chem. 177:751.

Greer, S. A. N., V. W. Hays, V. C. Speer and J. T. McCall. 1966. Effect of dietary fat, protein and cholesterol on atherosclerosis in swine. J. Nutr. 90:183.

Heidenreich, C. J., V. A. Garwood and R. B. Harrington. 1964. Swine growth and composition as associated with total serum cholesterol. J. Anim. Sci. 23:496.

Knill, L. M., T. R. Podleski and W. A. Childs. 1958. Normal values of swine serum proteins. Proc. Soc. Exp. Biol. Med. 97:224.

Kornegay, E. T., E. R. Miller, B. E. Brent, C. H. Long, D. E. Ullrey and J. A. Hoefer. 1964. Effect of fasting and refeeding on body weight, rectal temperature, blood volume and various constituents in growing swine. J. Nutr. 84:295.

Leveille, G. A. and R. W. Hanson. 1965. Influence of periodicity of eating on adipose tissue metabolism in the rat. Can. J. Physiol. Pharm. 43:857.

Leveille, G. A. and R. W. Hanson. 1966. Quantitative aspects of glutamate utilization by adipose tissue and liver in vitro: effect of periodicity of eating. Can. J. Physiol. Pharm. 44:273.

Mann, G. V. 1961. A method for measurement of total cholesterol in blood serum. Clin. Chem. 7:275.

McCance, R. A. 1960. Severe undernutrition in growing and adult animals. I. Production and general effects. Brit. J. Nutr. 14:59.

Miller, E. R., D. E. Ullrey, I. Ackerman, D. A. Schmidt, J. A. Hoefer and R. W. Luecke. 1961. Swine hematology from birth to maturity. I. Serum proteins. J. Anim. Sci. 20:31.

Morrow, R. E., A. M. Pearson, E. P. Reineke and J. A. Hoefer. 1956. Factors influencing blood lipid levels and relationship to carcass characteristics of swine. J. Anim. Sci. 15:1288. (Abstr.).

Morrow, R. E., A. M. Pearson, E. P. Reineke and J. A. Hoefer. 1963. Effects of feeding, fasting and environmental temperature upon blocd plasma lipid levels in swine. J. Anim. Sci. 22:466.

Perry, T. W., W. M. Beeson and B. W. Vosteen. 1953. The effect of an antibiotic or a surfactant on the growth and carcass composition of swine. J. Anim. Sci. 12:310.

RowselI, H. C., H. G. Downie and J. F. Mustard. 1958. The experimental production of atherosclerosis in swine following the feeding of butter and margarine. Can. Med. Ass. J. 79:647.

Rowsell, H. C., J. F. Mustard and H. G. Downie. 1965. Experimental atherosclerosis in swine. Ann. N. Y. Acad. Sci. 127:743.

Self, H. L. 1959. Blood fat levels in growing-finishing swine as influenced by sex, age, breed and ration. J. Anim. Sci. 18:561.

Steel, R. G. D. and J. H. Torrie, 1960. Principles and Procedures of Statistics. McGraw-Hill Book Co., Inc., New York.

Tremere, A. W., B. D. Owen and J. M. Bell. 1966. Relationships between blood serum lipid and protein constituents and carcass measurements in swine. J. Anim. Sci. 25:138.

Veum, T. L., W. G. Pond, L. D. Van Vleck, E. F Walker, Jr. and L. Krook. 1970. Effect of feedingfasting interval on finishing pigs: weight gain, feed utilization and physical and chemical carcass measurements. J. Anim. Sci. 30:382. 